\title{
Botulinum toxin type for the management of masticatory muscle pain in temporomandibular disorders: a systematic review
}

\begin{abstract}
Background: Botulinum toxin type A (BoT-A) has gained significant clinical interest in the management of masticatory muscle pain in temporomandibular disorders (TMD). This may be due to clinical success of BoT-an in treatment of other neuromuscular and refractory chronic pain disorders in the head and neck region, and the limited understanding of the underlying pathophysiology of masticatory muscle pain.
\end{abstract}

Methods:A systematic review was conducted to determine the effectiveness of botulinum toxin type $\mathrm{A}$ in the management of masticatory muscle pain in temporomandibular disorders, specifically myalgia, or myofascial pain. Three reviewers separately identified the pertinent literature by searching MEDLINE via PubMed, Web of science and Cochrane databases and reference lists of relevant articles under the inclusion criteria of all studies in English language.

Results: Thirteen manuscripts met the inclusion criteria. Among these six were randomized controlled trials (RCT) and seven were case-series investigations. Two out of 6 RCT and all of the 7 case-series investigations have suggested BoT-A therapy being significantly better in management of masticatory muscle pain in TMD.

Conclusion: The effectiveness of BoT-A treatment for the management of masticatory muscle pain in TMD has yet to be established. Results of both types of investigations are convoluted by the presence of multiple methodological limitations and heterogeneity in protocol. Botulinum toxin injection therapy appears to effective in certain patients with masticatory muscle pain disorders in TMD. However, there is limited evidence regarding the characterization of participants that would benefit from this therapeutic modality

Keywords: temporomandibular disorders, botulinum toxin, myalgia, masticatory muscle pain, pain
Volume 7 Issue 6 - 2017

\author{
Shehryar N Khawaja, ${ }^{1,2,3}$ Heidi Crow, ${ }^{3}$ Tomas \\ Holmlund, ${ }^{4}$ Yoly Gonzalez ${ }^{3}$ \\ 'Department of Oral and Maxillofacial Surgery, Massachusetts \\ General Hospital, USA \\ ${ }^{2}$ Harvard School of Dental Medicine, USA \\ ${ }^{3}$ Department of Oral Diagnostic Sciences, University at Buffalo, \\ USA \\ ${ }^{4}$ Department of Neurology, University at Buffalo, USA
}

Correspondence: Shehryar N Khawaja, Department of Ora and Maxillofacial Surgery, Massachusetts General Hospital, 55 Fruit Street, Suite Warren I201, Boston, Massachusetts 021 I4, USA, Tel I4357I0 1080, Fax I7I68293554,

Email khawajashehryar@gmail.com

Received: March 21, 2017| Published: August 10, 2017

\section{Introduction}

Temporomandibular disorders (TMD) encompass a group of musculoskeletal and neuromuscular conditions that involve the temporomandibular joints (TMJs), the masticatory muscles, and associated tissues. ${ }^{1}$ The prevalence of pain-related TMD, such as, masticatory myalgia, masticatory myofascial pain and TMJ arthralgia, has been reported to be between $2.5 \%$ to $10 \%$ in the general adult population, making it the second most common musculoskeletal condition, after chronic back pain, which results in pain and disability. ${ }^{2,3}$ Common manifestations of pain-related TMD consist of pain, of a persistent, recurring, or chronic nature, ${ }^{4,5}$ limitation in the range of mandibular motion, and joint noises. ${ }^{4-6}$ Pain-related TMD can affect the individual's daily activities, psychosocial functioning, and quality of life. ${ }^{7}$ It has been estimated that the annual pain-related TMD management cost in the United States, excluding diagnostic imaging, in the last decade was approximately $\$ 4$ billion. Furthermore, in the United States, it is estimated that for every 100 million working adults, pain-related TMD contributes to 17.8 million lost workdays annually., ${ }^{9} 10$ Although the pathophysiology of painrelated TMD is poorly understood, multiple risk factors have been identified, such as, gender, pain provoked during jaw function and/ or palpation, oral parafunctions, other chronic pain conditions, pain sensitivity and psychosocial characteristics. ${ }^{11,12}$ Multiple treatment modalities have been suggested as a treatment for masticatory muscle pain disorders, including patient education, behavioral management, physical therapy, occlusal splints, and pharmacotherapy. ${ }^{6-14}$ However, no specific therapy has been proven uniformly effective in providing symptomatic relief. ${ }^{13}$ Because of this, the search for effective and safe therapies has been topic of interest among researchers. An example of such therapy is the emergence of botulinum toxin type A (BoT-A) as a potential therapeutic modality for management of masticatory muscle pain in TMD. Botulinum toxin type $\mathrm{A}$ is a subtype of a potent biologic toxin produced by Clostridium botulinum, a presynaptic neurotoxin. It blocks the calcium ion-mediated release of acetylcholine at the neuromuscular junction. The primary effect is on alpha-motor neuron function. However, it has been suggested that it may also alter the functioning of gamma-motor neurons in the muscle spindles. ${ }^{15,16}$ Independent of the neuromuscular effects, BoT-A has been suggested to have analgesic properties. ${ }^{16,17}$ However, the mechanism by which the analgesic effects are mediated is not fully understood. Animalbased investigations suggest BoT-A inhibits neurogenic inflammation by peripherally blocking the release of inflammatory neuropeptides, such as, substance $\mathrm{P}(\mathrm{SP})$ and glutamate. ${ }^{17,18}$ In addition, BoT-A has 
been found to inhibit the release of Calcitonin Gene-Related Peptide (CGRP),${ }^{18}$ and reduce the vascular response to algogenic substances, such as capsaicin, applied to human skin. ${ }^{1}$ Botulinum toxin type-A may also act centrally, it has been suggested that it may undergo retrograde transportation by sensory neurons and inhibit the release of neurotransmitters at the central nerve terminals. ${ }^{17-20}$ Intra-muscular administration of botulinum toxin has shown to be significantly useful in the management of muscle hyperactivity disorders, such as cervical dystonia, spasmodic dystonia, or blepharospasm. ${ }^{21,22}$ In addition to the reduction in dystonia-associated muscle hyperactivity, it has been shown to reduce the associated pain. ${ }^{15-21}$ Masticatory muscle hyperactivity in TMD and its associated pain have been suggested as self-perpetuating in nature. ${ }^{23}$ However, based on multiple EMGbased investigations, current evidence suggests that TMD-associated pain is correlated with muscle hypoactivity. ${ }^{23-25}$ Botulinum toxin has also been shown to be clinically beneficial in the management of refractory chronic pain disorders when injected into the soft-tissue (subcutaneously or intra-muscularly) as in case of chronic migraine headaches ${ }^{26,27}$ and trigeminal neuralgia. ${ }^{28,29}$ Likewise, it has been shown to be effective when injected intra-articularly for the management of refractory arthritis joint pain. ${ }^{30,31}$ The proposed mechanism of relief has been attributed to the neuro-inhibitory and anti-nociceptive properties of the toxin along the peripheral and central nervous system. ${ }^{17}$ The clinical success of BoT-A in treatment of neuromuscular and refractory chronic pain disorders in the head and neck region, and the limited understanding of the underlying pathophysiology of pain in TMD as well as the refractory nature of pain in some cases, may explain the clinical interest of physicians in the use of BoT-A in the management of masticatory muscle pain in TMD. The U.S. Food and Drug Administration (FDA) and the European Medicines Agencies (EMA) have not yet approved use of BoT-A to manage masticatory muscle pain in TMD. Nevertheless, it is being used and promoted as an off-label indication. ${ }^{32}$ Several studies have been conducted on the effectiveness of BoT-A for the management of masticatory muscle pain in TMD. However, the results have been inconsistent. While some of the studies have reported evidence for its efficacy, others have reported inconclusive findings. Due to this difference in reporting, a systematic review was conducted to determine the effectiveness of BoT-A in the management of masticatory muscle pain in TMD, specifically masticatory myalgia, or masticatory myofascial pain.

\section{Materials and methodology}

The PRISMA guidelines were used as a template for the systematic review. The clinical question, "Is botulinum toxin A more efficacious than placebo treatment for management of pain associated with masticatory myalgia among patients of TMD, in an out-patient setting?" (PICOS) was utilized to guide the review. Observational investigations evaluating the effectiveness of BoT-A for treatment of masticatory muscle pain in TMD, specifically masticatory myalgia or masticatory myofascial pain were included. Publications were limited to English language, humans, and adults ( $\geq 16$ years) only. Publication date limit for the selection of articles was from beginning to June 2016. Publications such as literature reviews and case-reports were excluded from this review. Three reviewers separately identified the pertinent literature by searching MEDLINE via PubMed, The web of science, and Cochrane databases and reference lists of relevant articles for manuscripts meeting the inclusion and exclusion criteria. The databases were searched using relevant keywords and MeSH terms. The search strategy was: ("botulinum toxin" $[\mathrm{MeSH}])$ OR ("botulinum toxin type A"[MeSH]) OR (clostridium botulinum)
OR (clostridium botulinum toxin) OR (onabotulinumtoxinA) OR (Abobotulinumtoxin) OR (botox) AND ("Myofascial Pain Syndromes"[MeSH]) OR ("myalgia"[MeSH]) OR ("masticatory muscle" $[\mathrm{MeSH}]$ ) OR ("temporomandibular joint dysfunction syndrome"[MeSH]) OR ("facial pain"[MeSH]). Overview of the procedure is provided in figure 1 . Three reviewers independently read the title and the abstract of all publications that were identified by the search strategy. The reviewers met and developed a final list of publications to be read by consensus. One reviewer read all the papers (SNK); the other two reviewers (HC, YG) equally divided the number of papers so that two reviewers evaluated each paper independently. Articles were reviewed based on the study design, aim of the study, demographics, clinical assessment methodology, botulinum toxin A type and protocol of administration, results, conclusions, adverse events, and limitations. In addition, the randomized controlled trials were assessed using Cochrane collaboration's tool for assessing risk of bias, ${ }^{33}$ while rest of the investigations were assessed using Newcastle-Ottawa quality assessment scale for case-control studies. ${ }^{34}$ Any disagreements between the reviewers were resolved through discussions and final decisions were reached through consensus.

\section{Results}

Three databases (MEDLINE via PubMed, The web of science, and Cochrane databases) and reference lists of relevant articles were systematically searched for articles. A total of 3.198 articles were identified with the search strategy. Three reviewers independently reviewed titles and abstracts of all of the identified manuscripts. The reviewers met and developed a final list of publications to be read by consensus. Three thousand one hundred and eighty five publications were excluded because of at least one of the following reasons: did not assess the effect of BoT-A on masticatory muscle pain associated with TMD, were case-reports or literature reviews, were not in the English language, or were based on animal-models. Thirteen met the inclusion criteria. Of these, 6 were randomized control trials (RCTs), and 7 were non-randomized case-series investigations. The randomized controlled trials included in the present systematic review were prospective human controlled trials, published between 2002 and 2012. ${ }^{35-40}$ Of the six RCTs, two were crossover studies ${ }^{35-39}$ and four were parallel design studies. ${ }^{36-40}$ Each investigation evaluated participants using standardized examination protocol except one trial. ${ }^{40} \mathrm{All}$ of the participants were given diagnosis of either "masticatory myofascial pain" with or without "bruxism" and "functional disc displacement", or of "chronic facial pain associated with or caused by masticatory hyperactivity, parafunctional movements, and hypermobility disorders". Furthermore, included participants had chronic symptomatology $(3>$ months) and were refractory to conservative therapy (such as, behavior modification, thermal therapy, physical therapy, and occlusal orthotic device therapy). In total, 200 individuals (mostly females) participated, of which 133 underwent botulinum toxin injection therapy. The location and technique of injections varied. Injections were primarily placed in masseter muscles. However, in few studies injections were also placed in temporalis and medial pterygoid muscles. Injections were placed in either a pre-determined area using a specified pattern, such as chessboard or reverse pyramid, or corresponding to the site of maximum pain, or at the "most active site" of the muscle, based on manual palpation or EMG guidance. The total dose of botulinum toxin injected ranged from of $30 \mathrm{U}-50 \mathrm{U}$ per side for masseter muscles, 20U-35U per side for temporalis muscles, and up to $35 \mathrm{U}$ per side for medial pterygoid muscles. In all of the trials, groups receiving BoT-A 
therapy, has reduction in pain intensity and improvement in range of motion. However, these changes were statistically significant in only two of the six trials. Four of the six investigations reported minor adverse events, such as, discomfort/pain (4), transient facial paralysis (3), headache (7), fatigue (2), influenza like symptoms (2), dry mouth (1), difficulty with swallowing (1) and smiling (4) in association with BoT-A therapy. Overall, 3 of the 6 RCT investigations failed to reject the null hypothesis. However, 2 of these investigations were underpowered $(<50 \%)$. The study characteristics are summarized in Table 1. The quality of the RCT was assessed using Cochrane risk of bias tool for randomized controlled trials. Three of the six RCT were classified as having unclear risk of selection bias because either limited evidence was provided regarding the randomization sequence generation or limited information was present regarding the allocation concealment. One of the included trials had high risk of performance bias. $^{37}$ In this particular investigation, the corresponding group underwent facial manipulation, which would have not made possible for blinding of the participants and researcher. Overall, majority of investigations had low risk of detection, attrition, and reporting bias. Table 2 presents the individual domain risk of bias for each of the included RCT. The non-randomized observational studies selected in this systematic review were case-series, published between 1999 and 2013. Participants were given the diagnosis of "masticatory myofascial pain", "muscle-centered TMD", "chronic facial pain", or "TMD" with or without "bruxism", "Chronic tension type headache", and "muscle hyperactivity". Similar to RCT, all of the participants had chronic symptomatology ( $3>$ months) and were refractory to conservative therapy. The location and protocol of injection therapy was variable. Injections were primarily placed in the masseter and the temporalis muscles. However, in some investigations medial pterygoid muscles were also injected. Injections were placed in either a pre-determined area using a specified pattern, such as chessboard or reverse pyramid, or corresponding to the site of maximum pain, or at the site of "maximum muscle thickness", using manual palpation or EMG guidance. The dosage of injection for each muscle varied from $7.5 \mathrm{U}-200 \mathrm{U}$ per side. All of the studies reported reduction in pain symptoms at follow-up. Transient adverse reactions were reported in four of the seven case-series. These consisted of facial muscle weakness and wasting (1), difficulty with speech and swallowing (2), muscle fatigue (35), headaches (3), bruising (1), and facial asymmetry (10). One study was found to be underpowered $(<50 \%)$. Six out of seven trials rejected the null hypothesis. However, reduction in pain after undergoing BoT-A injections was found to be statistically significant in all 7 investigations. The study characteristics are categorized and tabulated in Table 3. The quality of non-randomized case-series investigations was evaluated using Newcastle-Ottawa assessment scale for case-control studies. Based on the scale, all of the investigations scored 2 stars on the selection criteria, and 1 star on exposure criteria. No star was awarded to any investigation in comparability category. The results are summarized in Table 4.

Table I Assessment of randomized controlled trials using Cochrane collaboration's tool for assessing risk of bias tool

\begin{tabular}{|c|c|c|c|c|c|c|}
\hline & Guarda-Nardini ${ }^{36}$ & Ernberg $^{35}$ & Kortoglu ${ }^{38}$ & Guarda-Nardini ${ }^{36}$ & Von Lindern ${ }^{40}$ & Nixdorff ${ }^{39}$ \\
\hline Random sequence generation & + & + & + & $?$ & $?$ & + \\
\hline Allocation concealment & $?$ & + & + & $?$ & $?$ & + \\
\hline Blinding of participants and personnel & - & + & + & - & $?$ & + \\
\hline Blinding of outcome assessment & + & + & + & $?$ & + & + \\
\hline Incomplete outcome date & + & + & + & + & $?$ & - \\
\hline Selective reporting & + & + & + & + & $?$ & $?$ \\
\hline Other bias & ? & ? & - & - & - & - \\
\hline
\end{tabular}

Low risk (+), High risk (-), Unclear risk (?)

Table 2 Summary of the randomized control trials included in the systematic review

\begin{tabular}{llll}
\hline Author and year Study design and aim Demographics & $\begin{array}{l}\text { Clinical } \\
\text { assessment } \\
\text { methodology }\end{array}$ & $\begin{array}{l}\text { Botulinum Toxin a type } \\
\text { and protocol }\end{array}$ \\
\hline
\end{tabular}

\begin{tabular}{|c|c|c|c|}
\hline & & $N=30$ & \\
\hline Guarda Nardini L et al. ${ }^{37}$ & $\begin{array}{l}\text { RCT (not blinded) } \\
\text { Parallel design } \\
\text { Aim:To determine the } \\
\text { effectiveness of FM } \\
\text { technique and BTA } \\
\text { injections for the treatment } \\
\text { of myofascial pain over } 3 \\
\text { months. }\end{array}$ & $\begin{array}{l}22 \text { q, } 8 \text { } \\
\text { BTA Group Age: } \\
47.7 \pm \mid 4.3 \text { yrs. } \\
\text { FM Group Age: } \\
43.2 \pm \mid 3.9 \text { yrs. } \\
\text { All of the participants } \\
\text { were given a diagnosis } \\
\text { of bilateral "myofascial } \\
\text { pain" for } \geq 6 \text { months. } \\
\text { Participants with } \\
\text { neurological, } \\
\text { rheumatological, } \\
\text { concurrent Arthralgia, } \\
\text { or OA were excluded. }\end{array}$ & $\begin{array}{l}\text { Participants } \\
\text { underwent RDC/ } \\
\text { TMD examination. } \\
\text { VAS for pain } \\
\text { intensity. } \\
\text { Assessments } \\
\text { performed at } \\
\text { baseline, post- } \\
\text { injection and after } \\
\text { months. }\end{array}$ \\
\hline
\end{tabular}

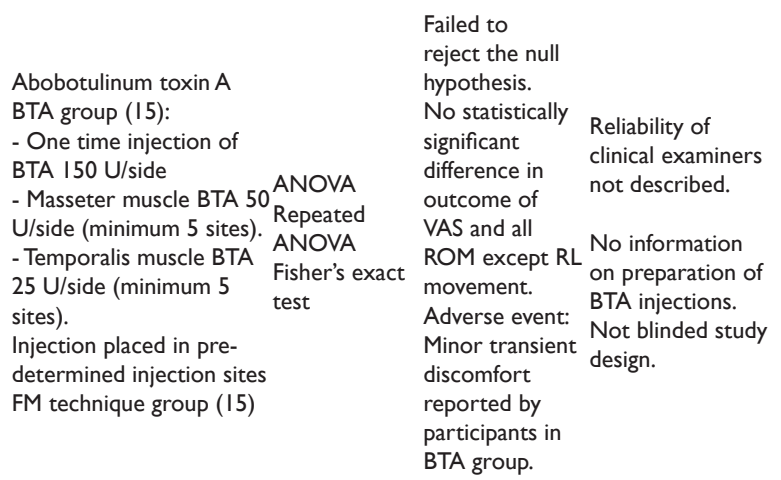


Table continued...

\begin{tabular}{|c|c|c|c|c|c|c|c|}
\hline Author and year & Study design and aim & Demographics & $\begin{array}{l}\text { Clinical } \\
\text { assessment } \\
\text { methodology }\end{array}$ & \multicolumn{2}{|c|}{$\begin{array}{l}\text { Botulinum Toxin a type } \\
\text { and protocolistics }\end{array}$} & Conclusions & Limitations \\
\hline Ernberg M et al..$^{35}$ & $\begin{array}{l}\text { RCT (double-blind) } \\
\text { Cross-over design } \\
\text { Aim: To test the hypothesis } \\
\text { that BTA is more effective } \\
\text { than isotonic saline for the } \\
\text { treatment of persistent } \\
\text { myofascial pain in TMD. }\end{array}$ & $\begin{array}{l}\mathrm{N}=2 \mathrm{I} \\
\mathrm{I} 9 \text { 9 }, 20 \\
\text { Age: } 38.0 \pm 12.0 \text { yrs. } \\
\text { Pain duration: } 6.3 \pm 4.7 \\
\text { yrs. } \\
\text { All of the participants } \\
\text { were given a diagnosis } \\
\text { of "myofascial pain". } \\
\text { All of the participants } \\
\text { undergone conservative } \\
\text { therapy } \geq 6 \text { months. } \\
\text { All of the participants } \\
\text { had an average pain } \\
\text { intensity of } \geq 30 \text { mm on } \\
\text { a } 0 \text { - I00VAS. } \\
\text { Participants with } \\
\text { systemic inflammatory } \\
\text { connective tissue } \\
\text { diseases, whiplash- } \\
\text { associated disorders, } \\
\text { fibromyalgia, } \\
\text { neuropathic pain or } \\
\text { neurological disorders, } \\
\text { pain of dental origin, } \\
\text { use of muscle relaxants, } \\
\text { or aminoglycoside } \\
\text { antibiotics were } \\
\text { excluded. }\end{array}$ & $\begin{array}{l}\text { Participants } \\
\text { underwent RDC/ } \\
\text { TMD examination. } \\
\text { VAS for pain } \\
\text { intensity. } \\
\text { MPQ for pain } \\
\text { assessment. } \\
\text { PPT and PPTol. } \\
\text { Participants were } \\
\text { assessed during, } \\
\text { after I month and } 3 \\
\text { months. } \\
\end{array}$ & $\begin{array}{l}\text { Onabotulinum toxin A } \\
\text { BTA group }(2 \mathrm{I}) \text { : } \\
\text { One time injection of BTA } \\
50 \mathrm{U} / \mathrm{side} \\
\text { (Diluted in saline) } \\
\text { Masseter muscle BTA } \\
50 \mathrm{U} / \mathrm{side}(10 \mathrm{U} / 0.1 \mathrm{~mL} \text {, } \\
3 \text { sites). } \\
\text { Control group (20): } \\
\text { One time injection } \mathrm{f} \text { saline } \\
\text { Masseter muscle } .5 \mathrm{~mL} \text { of } \\
\text { saline/side ( } 3 \text { sites) } \\
\text { Injection placed in } \\
\text { accordance with anatomy } \\
\text { with EMG guidance. }\end{array}$ & $\begin{array}{l}\text { 2-way repeatec } \\
\text { measure } \\
\text { ANOVA } \\
\text { Holm-Sidak } \\
\text { post Hoc test } \\
\text { Dunn's methoc } \\
\text { McNemar's } \\
\text { test }\end{array}$ & $\begin{array}{l}\text { Failed to } \\
\text { reject the null } \\
\text { hypothesis. } \\
\text { After I month } \\
\text { in BTA group } \\
\text { change in pain } \\
\text { intensity was } 30 \\
\text { compared to } \\
\text { II for control } \\
\text { group. } \\
\text { After } 3 \text { month } \\
\text { in BTA group } \\
\text { change in pain } \\
\text { intensity was } \\
23 \text { compared } \\
\text { to } 4 \text { for control } \\
\text { droup. } \\
9 \text { participants } \\
\text { in BTA group } \\
\text { compared to } 7 \\
\text { in control group } \\
\text { dhad } 30 \% \text { pain } \\
\text { reduction after } \\
\text { I month. } \\
7 \text { participants } \\
\text { in BTA group } \\
\text { compared to } 4 \\
\text { participants in } \\
\text { control group } \\
\text { had } 30 \% \text { pain } \\
\text { reduction after } \\
3 \text { months. } \\
\text { Adverse events: } \\
\text { Headache (7), } \\
\text { fatigue (2), } \\
\text { jaw pain (3), } \\
\text { influenza like } \\
\text { symptoms ( } 2 \text { ) } \\
\text { and dry mouth } \\
\text { ( } 1) \text { reported in } \\
\text { BTA group. }\end{array}$ & $\begin{array}{l}\text { Ptudy was } \\
\text { underpowered } \\
\text { (<50\%). } \\
\text { Small sample size. } \\
\text { Reliability of } \\
\text { clinical examiners } \\
\text { was not described. } \\
\text { Both sides } \\
\text { injected regardless } \\
\text { of the site of pain. } \\
\text { : } \\
\end{array}$ \\
\hline Kurtoglu C et al. ${ }^{38}$ & 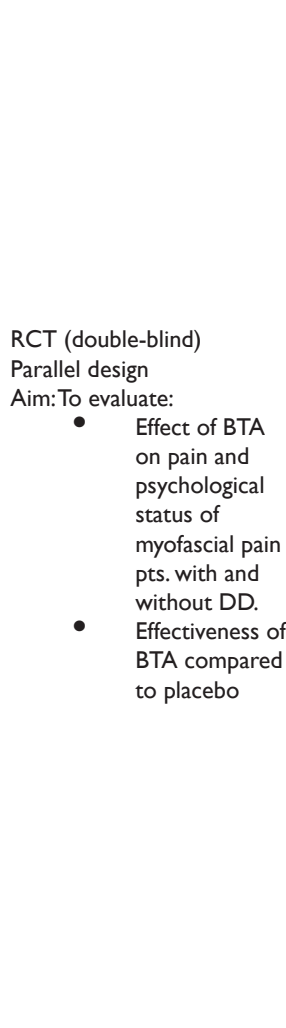 & $\begin{array}{l}\text { N=24 } \\
\text { BTA group: I } 2 \\
10 \text { + } 2 \text { O } \\
\text { Age: } 29.6 \pm 12.7 \text { yrs. } \\
\text { (I6-53 yrs.) } \\
\text { Placebo group: I } 2 \\
10 \text { + } 2 \text { O } \\
\text { Age: } 23.4 \pm 4.7 \text { yrs. } \\
\text { (20-34 yrs.) } \\
\text { All of the participants } \\
\text { were given a diagnosis } \\
\text { of "myofascial pain". } \\
\text { In addition, } 3 \text { in BTA } \\
\text { and } 8 \text { in placebo group } \\
\text { were given a diagnosis } \\
\text { of "Functional DD". } \\
\text { f All of the participants } \\
\text { had undergone } \\
\text { conservative TMD } \\
\text { therapy without relief of } \\
\text { symptoms. } \\
\text { Participants with age } \\
<14 \text { years, allergy to } \\
\text { botulinum toxin type } \\
\text { A, pregnant or lactating } \\
\text { were excluded. }\end{array}$ & $\begin{array}{l}\text { Participants } \\
\text { underwent RDC/ } \\
\text { TMD examination. } \\
\text { Participants were } \\
\text { assessed at baseline, } \\
\text { day } 14 \text {, and day } 28 \text {. } \\
\text { EMG was used for } \\
\text { assessment of muscle } \\
\text { activity. }\end{array}$ & $\begin{array}{l}\text { Onabotulinum toxin A } \\
\text { BTA group (I2): } \\
\text { One time } \\
\text { injection of } \\
\text { BTA I00 U/ } \\
\text { participant. } \\
\text { (Diluted in } \\
\text { saline) } \\
\text { Masseter } \\
\text { muscle } 30 \mathrm{U} / \\
\text { side (I0U/0.2 } \\
\text { cc, } 3 \text { sites) } \\
\text { Temporalis } \\
\text { muscle } 20 \mathrm{U} / \\
\text { side (I0U/0.2 } \\
\text { cc, } 2 \text { sites). } \\
\text { Saline group [12]: } \\
\text { One time } \\
\text { injection of } \\
2 \text { cc of saline/ } \\
\text { participant. } \\
\text { Masseter } \\
\text { muscle } \\
\text { injected . } 3 \mathrm{cc} \\
\text { (3 sites) } \\
\text { Temporalis } \\
\text { muscle } \\
\text { injected } .2 \mathrm{cc} \\
\text { (sites) } \\
\text { Injected into the } \\
\text { "most } \\
\text { active" site } \\
\text { of muscle as } \\
\text { determined } \\
\text { by palpation. }\end{array}$ & $\begin{array}{l}\text { Friedman test } \\
\text { Wilcoxon test } \\
\text { Mann-Whitney } \\
\text { U test } \\
\text { Fisher's exact } \\
\text { test } \\
\\
\end{array}$ & $\begin{array}{l}\text { Null hypothesis } \\
\text { was rejected. } \\
\text { No significant } \\
\text { difference found } \\
\text { in pain, disability, } \\
\text { and psychosocial } \\
\text { status between } \\
\text { two groups. } \\
\text { Statistical } \\
\text { difference } \\
\text { between placebo } \\
\text { and BTA group } \\
\text { was observed in } \\
\text { EMG at day I4. } \\
\text { Adverse events: } \\
\text { NR }\end{array}$ & $\begin{array}{l}\text { Small sample size } \\
\text { RDC-TMD } \\
\text { does not have } \\
\text { a diagnosis of } \\
\text { "Functional DD". } \\
\text { Participants were } \\
\text { followed up for } \\
\text { d a short duration } \\
\text { y, of time. } \\
\text { alBoth sides } \\
\text { injected regardless } \\
\text { of site of pain. } \\
\text { No clinical } \\
\text { success criteria } \\
\text { odefined. } \\
\text { Reliability of } \\
\text { clinical examiners } \\
\text { was not described. } \\
\text { : Inappropriate } \\
\text { criteria to } \\
\text { determine the } \\
\text { "most active" part } \\
\text { of the muscle. }\end{array}$ \\
\hline
\end{tabular}


Table continued...

Clinical

assessment methodology
Botulinum Toxin a type
and protocol
Conclusions Limitations

Onabotulinum toxin A.
BTA group (I0):
One time
injection
of I00 U/
participant
Injected.
Masseter
muscle
30 U/side
(4 sites).-
Temporalis
muscle 20 U/ 2 sample
$\quad$ side (3 sites). permutation
Control group (10): test
One time Anderson-
injection of Darling
saline.
Masseter $\quad$ permutation
muscle
injected (4
sites)
Temporalis
muscle
injected (3
sites)
Injection
placed in pre-
determined
injection
sites.

$\mathrm{N}=20$

10 \%, 100

All of the participants Participants

were given diagnoses of underwent

RCT (double - blind) Parallel design

Guarda Nardini L et al. ${ }^{36}$

\section{To investigate the}

efficacy of BTA for

treatment of myofascia

symptoms in bruxers. "myofascial pain" and

"bruxism".

Participants, who

underwent treatment

TMD examinatio

and a validated set of

screening criteria for

bruxism.

Assessment

bruxism in $\leq 6$ months, performed at

had neuromuscular baseline, I week,

pathologies or allergy to month, and 6 months.

botulinum toxin type $\mathrm{A}$

were excluded.
$\mathrm{N}=90$

BTA group $=60$

Placebo group $=30$

All of the participants were given a diagnosis of "Chronic facial pain caused by masticatory

RCT (single- blind) Parallel design

Aim:To investigate the

Von Lindern JJ et al. ${ }^{40}$ muscle hyperactivity, parafunctional

movements, and hypermobility disorders". BTA in the treatment of painful hyperactivity of the All of the participants masticatory ms.

had failed to respond

to $\geq 3$ months of

conservative therapy.

Participants with non-

muscular causes or

unclear patterns of

radiation of pain were

excluded.
Abobotulinum toxin $\mathrm{A}$

BTA group (60):

Participants

underwent clinical

examination and

function analysis.

VAS used for

assessment of pain

intensity.

Assessment

performed at

baseline and at 4

weeks.
- $19 / 60$

participants

were injected

$\geq 2$ times

(Diluted in

saline).

- Masticatory muscle BTA Chi-Square

$35 \mathrm{U} /$ muscle test

- $\quad(5 \mathrm{U} / 0.1 \mathrm{~mL})$

Placebo group (30):

Saline

injected

Injection

placed in pre-

determined

injection

sites
Study was

underpowered $(<50 \%)$

Null hypothesis No information was rejected. on age of ROM improved participants. in BTA group Small sample size.

but remained BTA injection constant in protocol not placebo group. adequately Pain reduced described. in BTA group Placebo injection but remained protocol not unchanged in adequately placebo group. described. Statistically No information significant on adverse effects. difference Success criteria observed in pain not defined. during chewing, P-values are perception not adjusted of treatment for multiple efficacy at 6 comparisons. month $\mathrm{f} / \mathrm{u}$. Effect of DD on the outcome of study not determined.
No information on demographics. Null hypothesis was rejected. Clinical 91 \% examination was participants had not adequately participants had described. improvement in Incomplete symptoms. outcome data Statistically provided. significant BTA injection improvement protocol not of $3.2 / 10$ in adequately the BTA group described. compared to Placebo injection $0.4 / 10$ in the protocol not placebo group. adequately Adverse events: described. Difficulty in Participants were swallowing and followed up for temporary facial short duration of muscle paralysis short $(n=1)$ 
Table continued..

Clinical

assessment

methodology

Botulinum Toxin a type statistics $_{\text {stin }}$

and protocol

Conclusions Limitations
Failed to

reject the null

hypothesis.

No statistically

significant

difference in

pain intensity.

Change in pain

intensity for Study was

BTA group was underpowered

$19 \mathrm{~mm}$. (<50\%).

Change in pain Only females.

intensity for Participants were

placebo group followed up for

was I $\mathrm{mm}$. short duration of

PFO and MUO time.

Aim:To derermine whether intensity of $\geq 50 \mathrm{~mm}$ on assessment of pain

Aim: To determine whether a 100 mm VAS. intensity.

Nixdorf DR et al. ${ }^{39}$

the masseter and temporicipants who were Success criteria

the masseter and temporalis lactating or pregnant, defined as reduction

ms. of patients with chronic or diagnosed with in VAS score of 20

inflammatory TMJ $\mathrm{mm}$ or increase of 6

function.

pathology, dental decay $\mathrm{mm}$ in $\mathrm{MO}$.

or intraoral soft tissue Assessments

lesions, history of TMJ performed at

surgery or trauma, baseline and 8 weeks.

neurological or bleeding

disorders, or actively on

opioids, aminoglycoside

antibiotics,

anticholinesterases,

muscle relaxants were

excluded.
$25 \mathrm{U} /$ side $(4.2 \mathrm{U} / 0.1$

$\mathrm{cm} 3,3$ sites).

Placebo group (12):

injection of

saline.

Paired t-test

- Masseter Logistic

muscle regression

injected with

$0.6 \mathrm{~cm}^{3}$ saline

(3 sites).

- Temporalis

muscle

injected with

$0.6 \mathrm{~cm} 3$

saline (3

sites)

Injection placed in

accordance

with anatomy

with EMG

guidance. improved Small sample size.

statistically in Only single point

placebo group. measurement in

5 participants time.

did not Data of successful

complete study outcome

due to use not provided

of prohibited separately for two

medicine (3) groups.

and paralysis of

muscle (2).

Adverse events:

Transient

paralysis of

zygomaticus

major ms. (2)

and difficulty in

smiling (4)

Table 3 Assessment of non-randomized studies using Newcastle-Ottawa quality assessment scale

\begin{tabular}{|c|c|c|c|}
\hline Study & Selection & Comparability & Exposure \\
\hline Sidebottom et al. ${ }^{48}$ & $\star \star$ & & $\star$ \\
\hline Freund et al. ${ }^{51}$ & $\star \star$ & & $\star$ \\
\hline Boradic et al. ${ }^{41}$ & $\star \star$ & & $\star$ \\
\hline Freund \& Schwartz $M^{47}$ & $\star \star$ & & $\star$ \\
\hline Von Lindern ${ }^{50}$ & $\star \star$ & & $\star$ \\
\hline Freund ${ }^{51}$ & $\star \star$ & & $\star$ \\
\hline Freund ${ }^{46}$ & $\star \star \star$ & & $\star$ \\
\hline
\end{tabular}

Citation: Khawaja SN, Crow H, Holmlund TG, et al. Botulinum toxin type for the management of masticatory muscle pain in temporomandibular disorders: a systematic review. J Dent Health Oral Disord Ther. 2017;7(6):4I I-424. DOI: 10.15406/jdhodt.20I7.07.00266 
Table 4 Summary of non-randomized controlled articles included in the systematic review

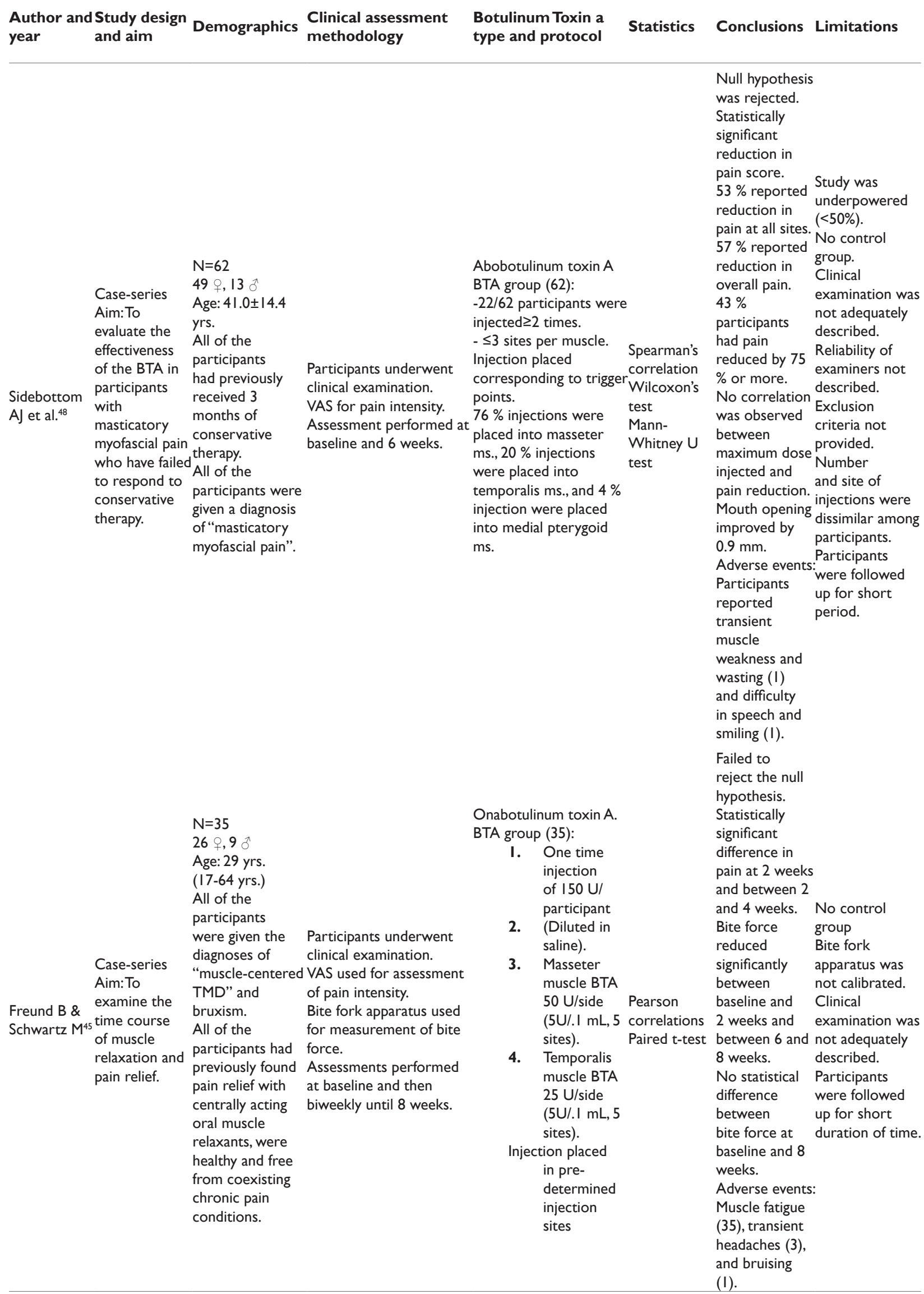


Table continued..

\begin{tabular}{|c|c|c|c|}
\hline $\begin{array}{l}\text { luthor and Study design } \\
\text { ear Dem and aim }\end{array}$ & $\begin{array}{l}\text { Clinical assessment } \\
\text { methodology }\end{array}$ & $\begin{array}{l}\text { Botulinum Toxin a } \\
\text { type and protocol }\end{array}$ & \\
\hline
\end{tabular}

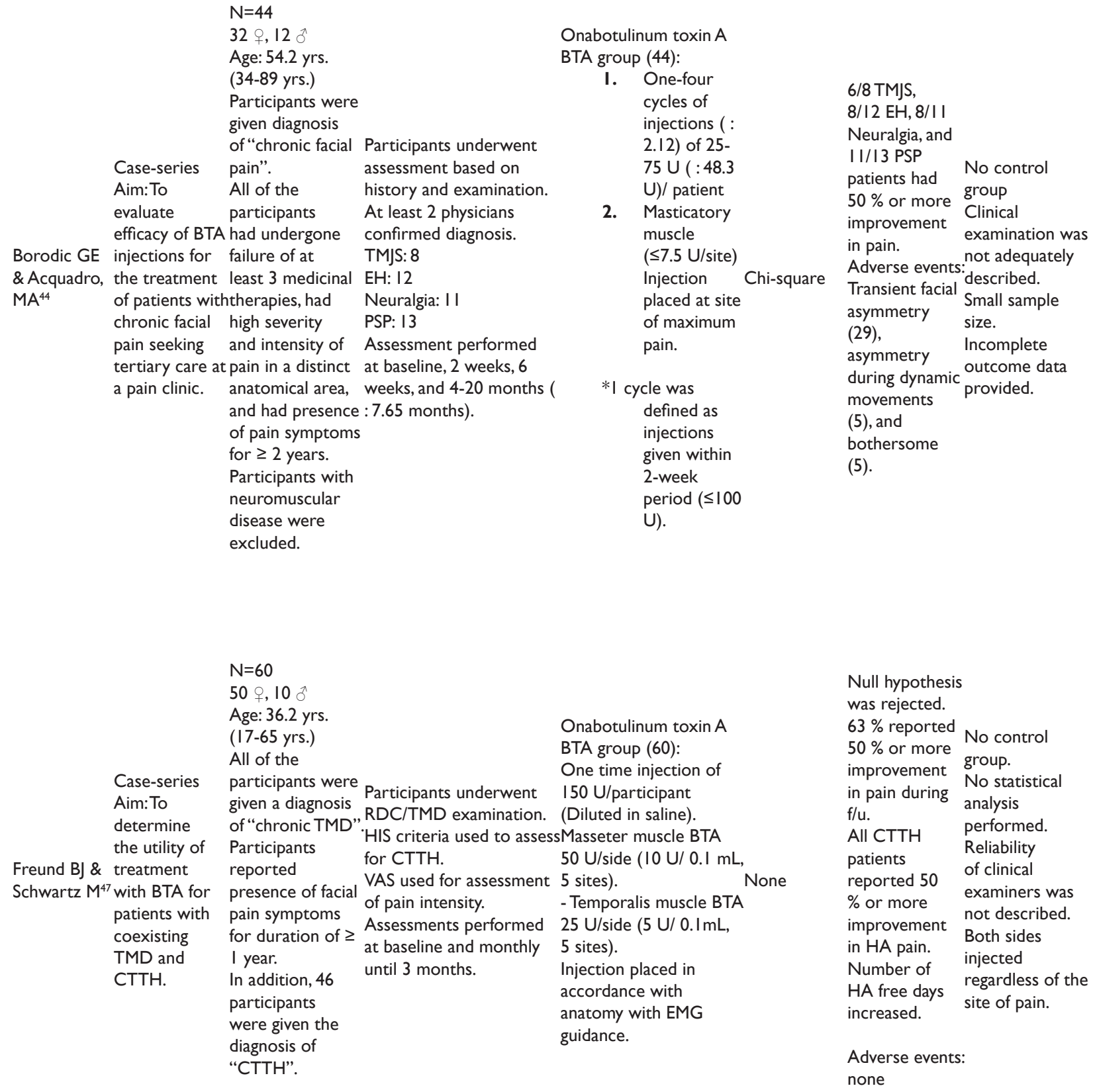


Table continued..

Author and Study design
year and aim Demographics $\begin{aligned} & \text { Clinical assessment } \\ & \text { methodology }\end{aligned} \quad \begin{aligned} & \text { Botulinum Toxin a } \\ & \text { type and protocol }\end{aligned}$ Statistics Conclusions Limitations

\begin{tabular}{|c|c|c|}
\hline & & $\mathrm{N}=4 \mathrm{I}$ \\
\hline & $\begin{array}{l}\text { Case-series } \\
\text { Aim:A } \\
\text { prospective } \\
\text { study to assess } \\
\text { the therapeutic }\end{array}$ & $\begin{array}{l}\text { All of the } \\
\text { participants } \\
\text { had "painful } \\
\text { masticatory } \\
\text { muscle } \\
\text { hyperactivity, } \\
\text { parafunctions, } \\
\text { and hypermobility } \\
\text { disorders". }\end{array}$ \\
\hline $\begin{array}{l}\text { Von Lindern } \\
\mathrm{JJ}^{50}\end{array}$ & $\begin{array}{l}\text { potential of } \\
\text { BTA in the } \\
\text { treatment } \\
\text { of painful } \\
\text { hyperactivity } \\
\text { of the } \\
\text { masticatory } \\
\text { muscles. }\end{array}$ & $\begin{array}{l}\text { All of the } \\
\text { participants } \\
\text { had previously } \\
\text { received } \\
\text { conservative } \\
\text { treatment for } \geq 3 \\
\text { months. } \\
\text { Participants with } \\
\text { non-muscular } \\
\text { causes or unclear } \\
\text { patterns of } \\
\text { radiation of pain } \\
\text { were excluded. }\end{array}$ \\
\hline
\end{tabular}

Null hypothesis group. was rejected. Participant $80 \%$ demographics participants not provided. had Clinical improvement examination was (45\%) in not adequately symptoms. described. I 3 participants BTA protocol had complete was not remission. adequately pain change described. was from 6.4 Reliability to 3.5. of clinical Symptoms examiners was reoccurred not described. within 3 Time-period months in 7 between and in $6.7 \pm 2.7$ injections cycle months in 34 not described. participants. Incomplete Adverse events:outcome data Speech and provided. swallowing No statistical difficulty (I). analysis performed.

$\mathrm{N}=46$

39 ㅇ, 7

Age: 40.5 yrs.

(16-75 yrs.)

All of the participants were

Case-series Aim:To Freund BJ. et evaluate the al. $^{51} \quad$ response of patients with TMD to BTA. given a diagnosis of "TMD".

Participants who were never given, or failed to respond to conservative therapy, had history of allergic reactions, pregnancy, or lactation were excluded.
Participants underwent RDC/TMD examination. VAS used for assessment

Onabotulinum toxin A

BTA group (46):

- One time injection

I. Pain

of I50 U / participant

2. Function

Bite fork apparatus

iluted in saline)

used for

Masseter muscle BTA Duncan's measurement $25 \mathrm{U} /$ side $(5 \mathrm{U} / 0.1 \mathrm{~mL})$.

Assessments made Injection placed in at baseline accordance with then biweekly anatomy with EMG until 8 weeks. guidance.
No control

group

Null hypothesis Reliability was rejected. of clinica Statistically examiners was significant not described. improvement Reliability of bite in VAS pain, fork apparatus VAS function, not described. opening of jaw, Participants and tenderness were followed to palpation. up for short No statistically duration of time. significant Both sides difference in injected bite force. regardless of the Adverse events:site of pain. none reported Incomplete outcome data provided. 
Table continued...

\begin{tabular}{|c|c|c|c|c|c|c|c|}
\hline $\begin{array}{l}\text { Author and } \\
\text { year }\end{array}$ & $\begin{array}{l}\text { Study design } \\
\text { and aim }\end{array}$ & Demographics & $\begin{array}{l}\text { Clinical assessment } \\
\text { methodology }\end{array}$ & $\begin{array}{l}\text { Botulinum Toxin a } \\
\text { type and protocol }\end{array}$ & Statistics & Conclusions & Limitations \\
\hline $\begin{array}{l}\text { Freund BJ et } \\
\text { al. }{ }^{46}\end{array}$ & $\begin{array}{l}\text { Case-series } \\
\text { Aim:To } \\
\text { evaluate the } \\
\text { response of } \\
\text { patients with } \\
\text { TMD to BTA. }\end{array}$ & $\begin{array}{l}\mathrm{N}=15 \\
13 \text { } 9,2 \text { } \\
\text { Age: } 39 \text { yrs. } \\
\text { ( } 16-75 \text { yrs.) } \\
\text { All of the } \\
\text { participants were } \\
\text { given a diagnosis } \\
\text { of "TMD". } \\
\text { Participants } \\
\text { who were never } \\
\text { given, or failed } \\
\text { to respond to } \\
\text { conservative } \\
\text { therapy, had } \\
\text { history of } \\
\text { allergic reactions, } \\
\text { pregnancy, or } \\
\text { lactation were } \\
\text { excluded. }\end{array}$ & $\begin{array}{l}\text { Participants underwent } \\
\text { RDC/TMD examination. } \\
\text { VAS used for assessment } \\
\text { of: } \\
\text { Pain } \\
\text { Functional } \\
\text { Bite fork apparatus used } \\
\text { measurement of bite } \\
\text { force. } \\
\text {, }\end{array}$ & $\begin{array}{l}\text { Onabotulinum toxin A } \\
\text { BTA group (I5): } \\
\text { - One time injection } \\
\text { of I } 50 \mathrm{U} / \text { participant } \\
\text { (Diluted in saline) } \\
\text { Masseter muscle BTA } \\
50 \mathrm{U} / \text { side ( } 10 \mathrm{U} / 0.1 \mathrm{~mL} \text { ) } \\
\text { - Temporalis muscle BTA } \\
25 \mathrm{U} / \text { side ( } 5 \mathrm{U} / 0.1 \mathrm{~mL} \text { ) } \\
\text { Injection placed in } \\
\text { accordance with } \\
\text { anatomy with EMG } \\
\text { guidance. }\end{array}$ & $\begin{array}{l}\text { Duncan's } \\
\text {.multiple } \\
\text { Arange test } \\
\text {. }\end{array}$ & $\begin{array}{l}\text { Null hypothesis } \\
\text { rejected. } \\
\text { Statistically } \\
\text { significant } \\
\text { improvement } \\
\text { in VAS pain, } \\
\text { VAS function, } \\
\text { opening of jaw, } \\
\text { and tenderness } \\
\text { to palpation. } \\
\text { No statistically } \\
\text { significant } \\
\text { difference in } \\
\text { bite force. } \\
\text { Adverse events: } \\
\text { none reported }\end{array}$ & $\begin{array}{l}\text { No control } \\
\text { group } \\
\text { Small sample } \\
\text { size } \\
\text { Both sides } \\
\text { sinjected } \\
\text { regardless of the } \\
\text { site of pain. } \\
\text { Reliability } \\
\text { of clinical } \\
\text { examiners was } \\
\text { not described. } \\
\text { Reliability of bite } \\
\text { fork apparatus } \\
\text { not described. } \\
\text { Participants } \\
\text { were followed } \\
\text { up for short } \\
\text { duration of time. } \\
\text { :Authors } \\
\text { recorded } \\
\text { psychosocial } \\
\text { characteristics } \\
\text { at baseline but } \\
\text { did not report } \\
\text { any f/u. }\end{array}$ \\
\hline
\end{tabular}

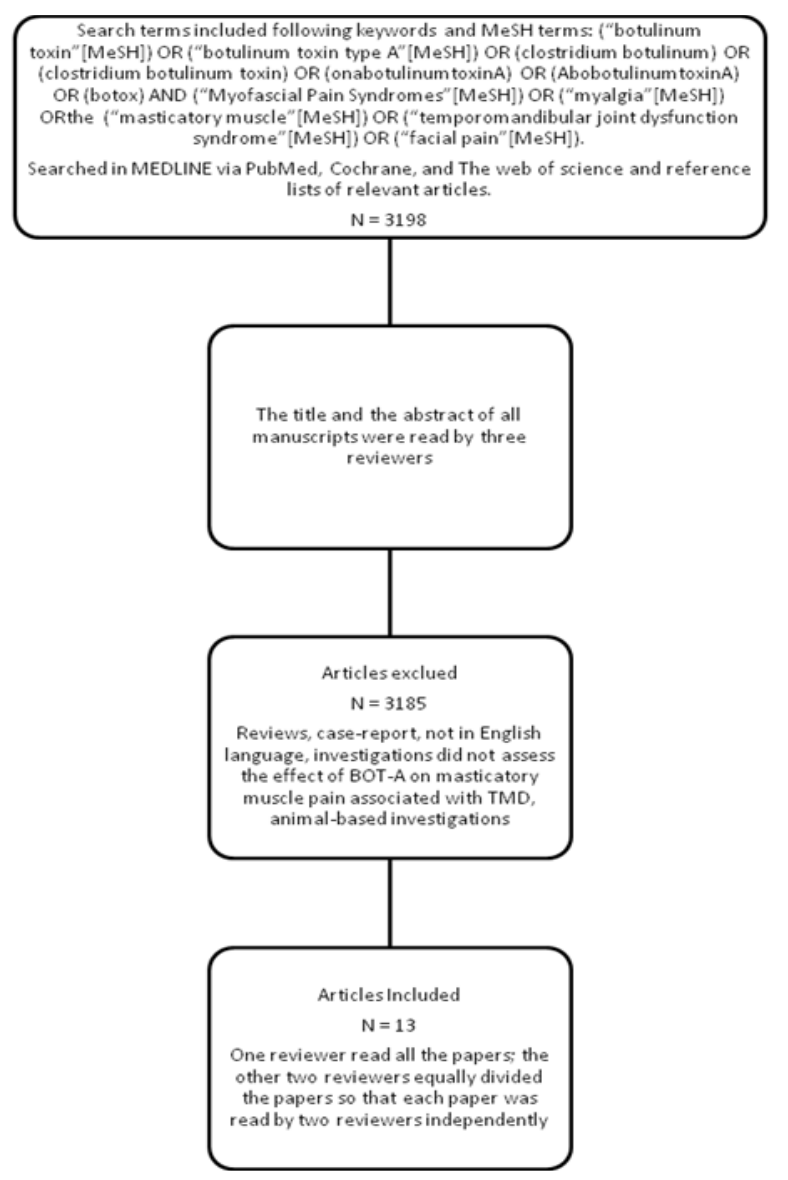

Figure I Overview of the search strategy. 


\section{Discussion}

A systematic review was conducted to determine the effectiveness of BoT-A in the management of masticatory muscle pain in TMD. Total of 13 articles published on this topic were reviewed. Two out of 6 RCT suggested BoT-A therapy was significantly better in management of masticatory muscle pain in TMD. In contrary, all of the 7 caseseries investigations suggested that BoT-A resulted in significant improvement in pain scores and range of motion in patients with masticatory muscle pain. Based on the review of RCT the therapeutic efficacy of the BoT-A therapy in management of masticatory muscle pain in TMD appears to be equivocal. This inconsistency in the literature may be attributed to multiple methodological variations, such as in the assessment of the subjects and injection protocol, risk of bias, and limitation in the research designs, such as, small sample sizes, ${ }^{35-38}$ short duration of the follow-up period, ${ }^{38,39}$ inadequate (low) statistical power, ${ }^{35-39}$ injecting into the muscle regardless of the site of pain, ${ }^{35-38}$ or as a one-time intervention. ${ }^{38,39}$ These limitations potentially convolute the results. Small sample sizes with short duration follow-up periods, inadequate time of collection of data $(<1$ hour after injections), or under powered investigations may not allow adequate appreciation of clinically beneficial effects, which may take 5 weeks or even more to be clinically noticeable and last for up to 4-6 months. ${ }^{41}$ It has been shown that clinically beneficial effects of BoT-A therapy tend to potentiate with the number of injection cycles, ${ }^{26}$ however it is not clear if such effects will take place in masticatory muscle pain patients with TMD. In addition, all of the investigations have relied on general sample of masticatory muscle pain patients. Musculoskeletal disorders associated with TMD and other conditions, have multiple underlying pathophysiological mechanisms. Though, they may present clinically with similar characteristics. It may be possible that botulinum toxin may help in disorders associated with specific etiologies (for e.g. muscle pain associated with hypertrophy or hyperactivity) and in general sample of TMD patients these effects may get clouded. Similarly, it has been reported that BoT-A may induce, or in some instances, patients may have pre-existing neutralizing antibodies against BoT-A. Although rare, it may result in clinical ineffectiveness of BoT-A therapy. ${ }^{42,43}$ Together, presence of such limitations may have influenced the results in favor of false negative findings. All seven of the case-series investigations found BoT-A therapy to be effective in management of masticatory muscle pain in TMD. However, these results need to be interpreted with caution. Case-series are considered low quality trials in the hierarchy of evidence because of the lack of randomization and blindness, and absence of a control arm. These methodological limitations in research design increase the risk of examiner and subject-associated bias. These risks were also highlighted in the current review by the outcome of Newcastle-Ottawa quality assessment tool. However, it can be argued that due to the acknowledged neuromuscular effects of BoT-A, both subjects and examiners are able to determine the group assignment. Therefore, case-series investigations may be given a consideration when compiling the results. Similarly, among articles reporting effectiveness of BoT-A treatment, some of the investigators failed to apply a standardized clinical examination, or report reliability of examiners to assess the masticatory pain associated with TMD. ${ }^{44-48}$ Together, these limitations may have influenced the results in favor of false positive findings. Among the studies investigated, multiple discrepancies in the protocol for BoT-A injection therapy for the management of masticatory muscle pain in TMD were found. The dosage of BoT-A injected varied from 25 units per muscle (one side) to up to 200 units per muscle (one side). Similar differences were observed for the volume and concentration of BoT-A injections. The volume of injected solution varied from .25 milliliters $(\mathrm{mL})$ per muscle to up to $1 \mathrm{~mL}$ per muscle, while the concentration of BoT-A also varied from 5 units per $0.1 \mathrm{~mL}$ to 40 units per $0.1 \mathrm{~mL}$. The optimal dosage of BoT-A depends on the anatomical characteristics of the individual muscle, such as mass and location, and on the severity of the symptomatology. However, there is no consensus on the therapeutic dosage. ${ }^{49}$ Based on our review, BoT-A therapy demonstrated acceptable safety levels. However, these results should be interpreted with caution. The sample sizes of investigations are relatively small and participants were followed for a short period of time. Adverse events associated with BoT-A therapy were transient (hours to weeks) and localized to the areas of injection. Participants reported discomfort at the site of injection, muscle weakness and wasting, difficulty in speech, smiling, and mastication, bruising, and facial asymmetry. Botulinum toxin type A has demonstrated similar safety levels for a variety of other indications. ${ }^{21,22}$ Recently, use of BoT-A in the orofacial region has been associated with changes in trabecular bone density. ${ }^{32}$ However, the magnitude of risk, genralizability of findings in male gender, and long-term clinical consequence has yet to be determined. Although rare, BoT-A may cause systemic adverse events. There have been reports of influenzalike symptoms, such as nausea, fatigue, upset stomach, and pruritus, as well as respiratory depression. In the present systematic review, a meta-analysis of the published literature was not conducted. This may be considered as a potential limitation. However, in order for the meta-analysis to be conducted, data has to be homogenous and free of any methodological limitations. Unfortunately, the included manuscripts do not fulfill these requirements..$^{50,51}$

\section{Conclusion}

The effectiveness of BoT-A treatment for the management of masticatory muscle pain in TMD has yet to be established. Based on the assessment of randomized controlled trials, the body of literature is equivocal. In contrast, review of case-series investigations suggests therapeutic beneficence of BoT-A therapy in the management of masticatory muscle pain in TMD. Furthermore, results of both randomized controlled trials and case-series investigations are convoluted by the presence of multiple methodological limitations, and heterogeneity in BoT-A injection protocol. Botulinum toxin injection therapy appears to effective in certain patients with masticatory muscle pain disorders. However, there is limited evidence regarding the characterization of participants that would benefit from this therapeutic modality in terms of duration, frequency, quality, and intensity of pain, associated signs and symptoms, with detailed medical history and valid diagnosis. This advocates the need for multi-center investigations with larger sample size and longer follow up periods, with adequate characterization of the participants in terms of diagnostic and therapeutic variables.

\section{Conflicts of interest}

The authors declare no potential conflicts of interest with respect to the authorship and/ or publication of this article.

\section{Acknowledgments}

None.

\section{Clinical implications}

Thirteen articles have been published regarding effectiveness 
of BoT-A in management of muscle pain in TMD. Two out of 6 randomized controlled trials (RCT) and all of the 7 case-series investigations have suggested BoT-A therapy being significantly better in management of masticatory muscle pain in TMD. Results of both RCT and case-series investigations are convoluted by the presence of multiple methodological limitations, and heterogeneity in BoT-A injection protocol. Botulinum toxin injection therapy appears to effective in certain patients with masticatory muscle pain disorders in TMD. However, there is limited evidence regarding the characterization of participants that would benefit from this therapeutic modality.

\section{Search strategy on PubMed}

("clostridium botulinum"[MeSH Terms] OR ("clostridium"[All Fields] AND "botulinum"[All Fields]) OR "clostridium botulinum"[All Fields]) OR Abobotulinumtoxin[All Fields] OR ("botulinum toxins"[MeSH Terms] OR ("botulinum"[All Fields] AND "toxins"[All Fields]) OR "botulinum toxins"[All Fields] OR ("clostridium"[All Fields] AND "botulinum"[All Fields] AND "toxin"[All Fields]) OR "clostridium botulinum toxin"[All Fields]) OR ("onabotulinumtoxinA"[Supplementary Concept] OR "onabotulinumtoxinA"[All Fields] OR "onabotulinumtoxina"[All Fields]) OR ("onabotulinumtoxinA"[Supplementary Concept] OR
"onabotulinumtoxinA"[All Fields] OR "botox"[All Fields]) AND "Myofascial Pain Syndromes" [MeSH] OR "myalgia" $[\mathrm{MeSH}]$ OR "temporomandibular joint dysfunction syndrome" $[\mathrm{MeSH}] \mathrm{OR}$ "facial pain”[MeSH] AND ((Clinical Trial[ptyp] OR Clinical Study[ptyp] OR Controlled Clinical Trial[ptyp] OR Randomized Controlled Trial[ptyp]) AND “humans”[MeSH Terms] AND English[lang])

\section{Search strategy on the web of science}

TOPIC: (botulinum toxin) OR TOPIC: ((onabotulinumtoxinA) OR (Abobotulinumtoxin)) OR TOPIC: (clostridium botulinum toxin A) OR TOPIC: (Botulinum Neurotoxin A) OR TOPIC: (Clostridium Botulinum Toxin Type A) OR TOPIC: (botulinum toxin type a) AND TOPIC: (myofascial pain syndrome) OR TOPIC: (myalgia) OR TOPIC: (temporomandibular joint dysfunction syndrome) OR TOPIC: (facial pain) OR TOPIC: (masticatory muscle)

\section{Search strategy on cochrane database}

((clostridium botulinum) OR (Abobotulinumtoxin) OR (botulinum toxins) OR (botulinum toxin A) OR (onabotulinumtoxinA) OR (botox))AND ((Myofascial pain) OR (Myofascial pain syndrome) OR (Myalgia) OR (Masticatory muscle) OR (Temporomandibular joint dysfunction) OR (Facial pain)) (Figures 2\&3).

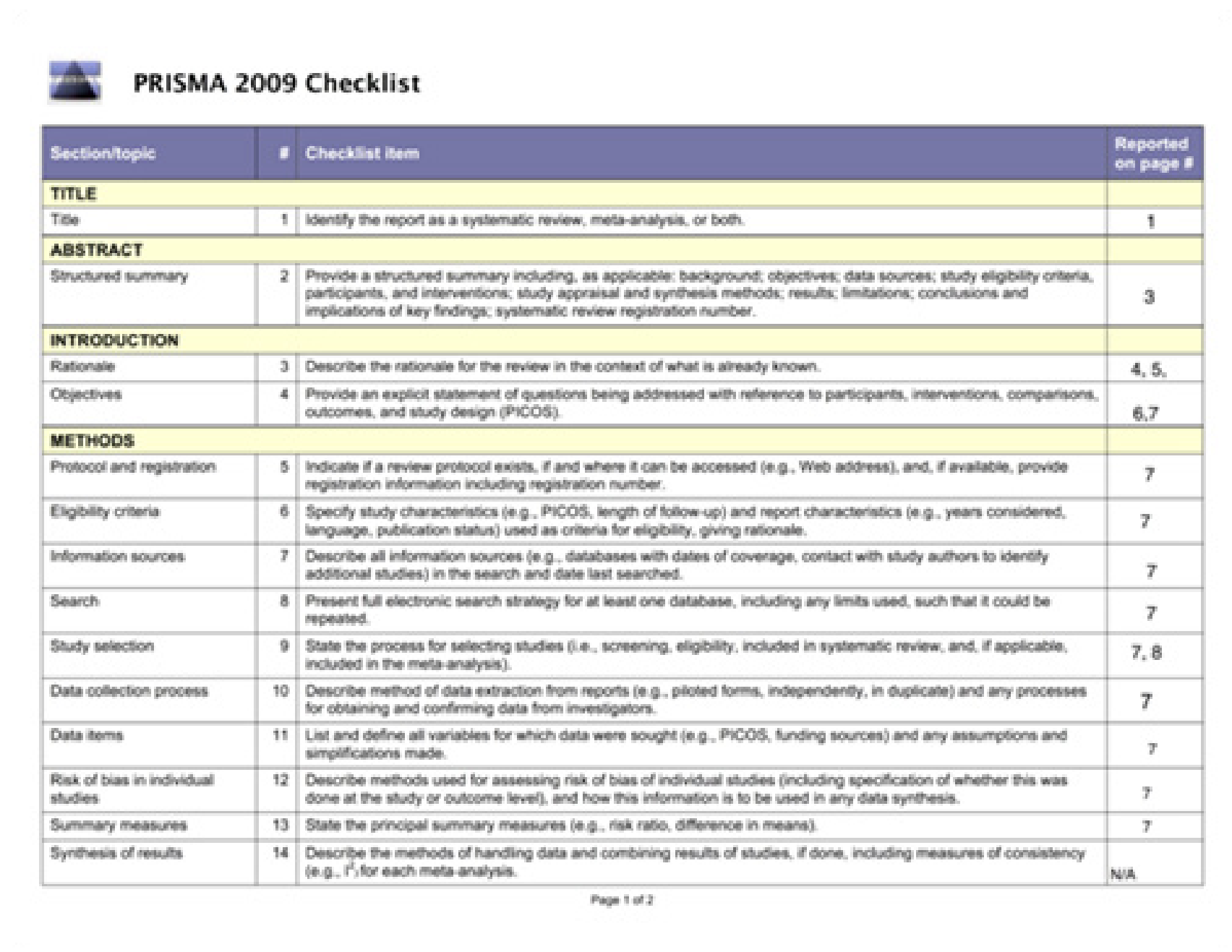

Figure 2

Citation: Khawaja SN, Crow H, Holmlund TG, et al. Botulinum toxin type for the management of masticatory muscle pain in temporomandibular disorders: a systematic review.J Dent Health Oral Disord Ther. 2017;7(6):4I I-424. DOI: 10.15406/jdhodt.20I7.07.00266 


\section{PRISMA 2009 Checklist}

\begin{tabular}{|c|c|c|c|}
\hline Sectionteple & $\bullet$ & Checklist item & $\begin{array}{l}\text { Reported } \\
\text { en paos }\end{array}$ \\
\hline Risk of bias acooss shudes & is & 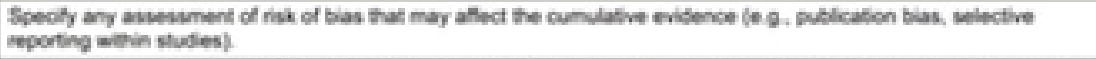 & 7 \\
\hline Adsilonal arilyes & 16 & 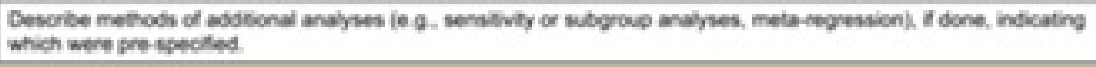 & Na \\
\hline \multicolumn{4}{|l|}{ RESULTS } \\
\hline Study selection & 17 & 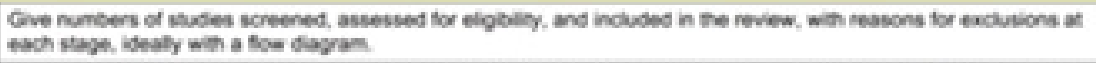 & 9. 10 \\
\hline Study characterabies & 18 & 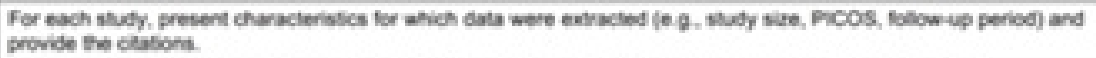 & $10, \pi$ \\
\hline Rak of bias within studes & 19 & 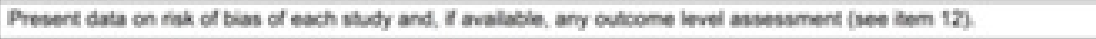 & $2 n, 20,2$ \\
\hline Results of individual sudes & 20 & 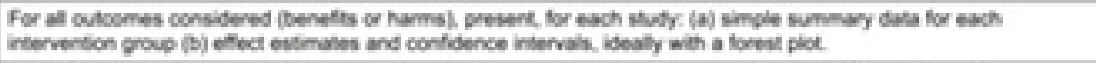 & $\begin{array}{l}211,2127 . \\
20-34\end{array}$ \\
\hline Synerevis of rewest & 21 & 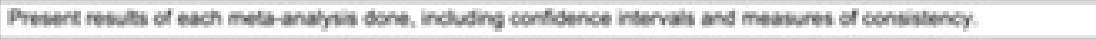 & NA \\
\hline Risk of bias acooss studies & $n$ & Present results of any assessment of nsk of bias across stubles (see them 15). & $10-12,20,2$ \\
\hline Adsitional andiris & 23 & 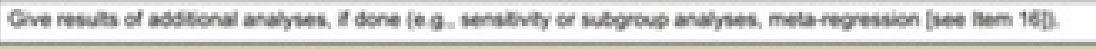 & NA \\
\hline \multicolumn{4}{|l|}{ Discussion } \\
\hline Summary of evidence & 24 & 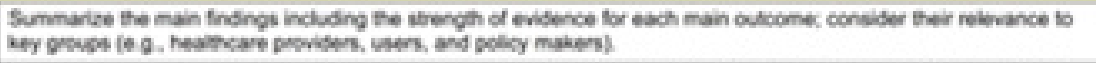 & $12-14$ \\
\hline Untations & 25 & 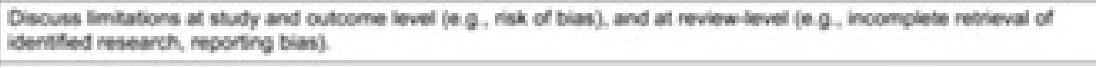 & $13-14$ \\
\hline Conclutions & 26 & 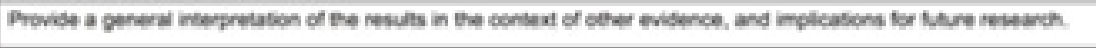 & 10413 \\
\hline \multicolumn{4}{|l|}{ FUNOING } \\
\hline funding & 27 & 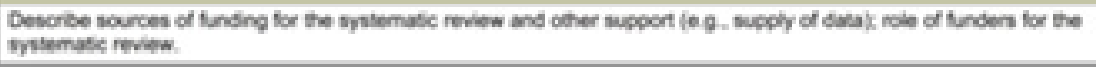 & is \\
\hline
\end{tabular}

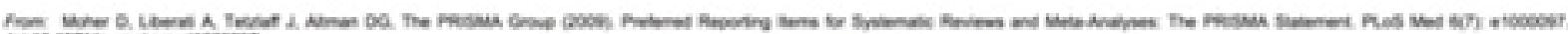
कon

Figure 3

\section{Funding}

None.

\section{Acknowledgments}

None.

\section{Conflicts of interest}

Author declares that there is no conflict of interest.

\section{References}

1. Greene CS. Diagnosis and treatment of temporomandibular disorders: emergence of a new care guidelines statement. Oral Surg Oral Med Oral Pathol Oral Radiol Endod. 2010;110(2):137-139.

2. LeResche L. Epidemiology of temporomandibular disorders: implications for the investigation of etiologic factors. Crit Rev Oral Biol Med. 1997;8(3):291-305.

3. Slade GD, Bair E, By K, et al. Study methods, recruitment, sociodemographic findings, and demographic representativeness in the OPPERA study. J pain. 2011;12(11 Suppl):T12-T26.

4. Ohrbach R, Burgess J. Temporomandibular Disorders and Orofacia Pain. In: Edward T Bope, et al. editors. Conn's Current Therapy. USA: Saunders, Pennsylvania; 2010. p. 992-997.
5. Dworkin SF, LeResche L. Research diagnostic criteria for temporomandibular disorders: review, criteria, examinations and specifications, critique. J Craniomandib Disord. 1992;6(4):301-55.

6. De Leeuw R, Klasser GD. Orofacial pain: guidelines for assessment, diagnosis, and management. $5^{\text {th }}$ ed, USA: Quintessence Publishing Co, Inc, Illinois; 2008. p. 1-312.

7. Slade GD, Bair E, Greenspan JD, et al. Signs and symptoms of first-onset TMD and sociodemographic predictors of its development: the OPPERA prospective cohort study. J pain. 2013;14(12 Suppl):T20-T32.

8. National Institute of Dental and Craniofacial Research. Facial Pain. USA.

9. Dworkin SF, Leresche L. Temporomandibular disorder pain: Epidemiologic data. APS Bulletin. 1993;12-13.

10. Maixner W, Diatchenko L, Dubner R, et al. Orofacial pain prospective evaluation and risk assessment study-the OPPERA study. $J$ Pain. 2011;12(11 Suppl):T4-T11.

11. Slade GD, Fillingim RB, Sanders AE, et al. Summary of findings from the OPPERA prospective cohort study of incidence of first-onset temporomandibular disorder: implications and future directions. $J$ pain. 2013;14(12 Suppl):T116-T124.

12. Ohrbach R, Fillingim RB, Mulkey F, et al. Clinical findings and pain symptoms as potential risk factors for chronic TMD: descriptive data and empirically identified domains from the OPPERA case-control study. $J$ pain. 2011;12(11 Suppl):T27-T45. 
13. List T, Axelsson S. Management of TMD: evidence from systematic reviews and meta-analyses. J Oral Rehabil. 2010;37(6):430-451.

14. Dworkin SF, Turner JA, Mancl L. A randomized clinical trial of a tailored comprehensive care treatment program for temporomandibular disorders. Carol Stream, IL, ETATS-UNIS, Quintessence. 2002. p. 18.

15. Simpson LL. The origin, structure, and pharmacological activity of botulinum toxin. Pharmacol Rev. 1981;33(3):155-188.

16. Aoki KR. Pharmacology and immunology of botulinum toxin type A. Clinics in dermatology. 2003;21(6):476-480.

17. Aoki KR. Evidence for antinociceptive activity of botulinum toxin type A in pain management. Headache. 2003;43 Suppl 1:S9-S15.

18. Meng J, Wang J, Lawrence G, et al. Synaptobrevin I mediates exocytosis of CGRP from sensory neurons and inhibition by botulinum toxins reflects their anti-nociceptive potential. Journal of cell science. 2007;120:2864-2874.

19. Gazerani P, Staahl C, Drewes AM, et al. The effects of Botulinum Toxin type A on capsaicin-evoked pain, flare, and secondary hyperalgesia in an experimental human model of trigeminal sensitization. Pain. 2006;122(3):315-325.

20. Paterson K, Lolignier S, Wood JN, et al. Botulinum toxin-a treatment reduces human mechanical pain sensitivity and mechanotransduction. Ann Neurol. 2014;75(4):591-596.

21. Jankovic J, Schwartz K, Donovan DT. Botulinum toxin treatment of cranial-cervical dystonia, spasmodic dysphonia, other focal dystonias and hemifacial spasm. J Neurol Neurosurg Psychiatry. 1990;53(8):633-639.

22. Roggenkamper P, Jost WH, Bihari K, et al. Efficacy and safety of a new Botulinum Toxin Type A free of complexing proteins in the treatment of blepharospasm. J Neural Transm. 2006;113(3):303-312.

23. Lund JP, Donga R, Widmer CG, et al. The pain-adaptation model: a discussion of the relationship between chronic musculoskeletal pain and motor activity. Can J Physiol Pharmacol. 1991;69(5):683-694.

24. Falla D, Farina D, Dahl MK, et al. Muscle pain induces task-dependent changes in cervical agonist/antagonist activity. $J$ Appl Physiol. 2007;102:601-609.

25. Svensson P, Arendt-Nielsen L, Houe L. Sensory-motor interactions of human experimental unilateral jaw muscle pain: a quantitative analysis. Pain. 1996;64(2):241-249.

26. Iener HC, Dodick DW, Aurora SK, et al. OnabotulinumtoxinA for treatment of chronic migraine: results from the double-blind, randomized, placebo-controlled phase of the PREEMPT 2 trial. Cephalalgia. 2010;30(7):804-814.

27. Jackson JL, Kuriyama A, Hayashino Y. Botulinum toxin A for prophylactic treatment of migraine and tension headaches in adults: a meta-analysis. JAMA. 2012;307:1736-1745.

28. Hu Y, Guan X, Fan L, et al. Therapeutic efficacy and safety of botulinum toxin type A in trigeminal neuralgia: a systematic review. $J$ Headache Pain. 2013;14:72.

29. Bohluli B, Motamedi MH, Bagheri SC. Use of botulinum toxin A for drug-refractory trigeminal neuralgia: preliminary report. Oral Surg Oral Med Oral Pathol Oral Radiol Endod. 2011;111(1):47-50.

30. Singh JA, Mahowald ML, Kushnaryov A, et al. Repeat injections of intraarticular botulinum toxin a for the treatment of chronic arthritis joint pain. J Clin Rheumatol. 2009;15(1):35-38.

31. Singh JA, Mahowald ML, Noorbaloochi S. Intra-articular botulinum toxin A for refractory shoulder pain: a randomized, double-blinded, placebocontrolled trial. Transl Res. 2009;153(5):205-216.
32. Raphael KG, Tadinada A, Bradshaw JM, et al. Osteopenic consequences of botulinum toxin injections in the masticatory muscles: a pilot study. $J$ Oral Rehabil. 2014;41:555-563.

33. Higgins JP, Altman DG, Gotzsche PC, et al. The Cochrane Collaboration's tool for assessing risk of bias in randomised trials. BMJ. 2011;343:d5928.

34. Wells G, Shea B, Oconnell D. The Newcastle-Ottawa Scale (NOS) for assessing the quality of nonrandomised studies in meta-analyses. 2000.

35. Ernberg M, Hedenberg-Magnusson B, List T, et al. Efficacy of botulinum toxin type A for treatment of persistent myofascial TMD pain: a randomized, controlled, double-blind multicenter study. Pain. 2011;152(9):1988-1996.

36. Guarda-Nardini L, Manfredini D, Salamone M, et al. Efficacy of botulinum toxin in treating myofascial pain in bruxers: a controlled placebo pilot study. Cranio. 2008;26(2):126-235.

37. Guarda-Nardini L, Stecco A, Stecco C, et al. Myofascial pain of the jaw muscles: comparison of short-term effectiveness of botulinum toxin injections and fascial manipulation technique. Cranio. 2012;30(2):95-102.

38. Kurtoglu C, Gur OH, Kurkcu M, et al. Effect of botulinum toxin-A in myofascial pain patients with or without functional disc displacement. $J$ Oral Maxillofac Surg. 2008;66(8):1644-1651.

39. Nixdorf DR, Heo G, Major PW. Randomized controlled trial of botulinum toxin A for chronic myogenous orofacial pain. Pain. 2002;99(3):465-473.

40. Von Lindern JJ, Niederhagen B, Berge S, et al. Type A botulinum toxin in the treatment of chronic facial pain associated with masticatory hyperactivity. J Oral Maxillofac Surg. 2003;61(7):774-778.

41. Borodic GE, Acquadro M, Johnson EA. Botulinum toxin therapy for pain and inflammatory disorders: mechanisms and therapeutic effects. Expert Opin Investig Drugs. 2001;10(8):1531-1544.

42. Greene P, Fahn S, Diamond B. Development of resistance to botulinum toxin type A in patients with torticollis. Mov Disord. 1994;9(2):213-217.

43. Jankovic J, Schwartz K. Response and immunoresistance to botulinum toxin injections. Neurology. 1995;45(9):1743-1746.

44. Borodic GE, Acquadro MA. The use of botulinum toxin for the treatment of chronic facial pain. J Pain. 2002;3(1):21-27.

45. Freund B, Schwartz M. Temporal relationship of muscle weakness and pain reduction in subjects treated with botulinum toxin A. J Pain. 2003;4:159-165.

46. Freund B, Schwartz M, Symington JM. The use of botulinum toxin for the treatment of temporomandibular disorders: preliminary findings. J Oral Maxillofac Surg. 1999;57(8):916-920; discussion 20-21.

47. Freund BJ, Schwartz M. Relief of tension-type headache symptoms in subjects with temporomandibular disorders treated with botulinum toxin-A. Headache. 2002;42(10):1033-1037.

48. Sidebottom AJ, Patel AA, Amin J. Botulinum injection for the management of myofascial pain in the masticatory muscles. A prospective outcome study. Br J Oral Maxillofac Surg. 2013;51(3):199-205.

49. Munchau A, Bhatia KP. Uses of botulinum toxin injection in medicine today. BMJ. 2000;320:161-165.

50. Von Lindern JJ. Type A botulinum toxin in the treatment of chronic facial pain associated with temporo-mandibular dysfunction. Acta neurologica Belgica. 2001;101(1):39-41.

51. Freund B, Schwartz M, Symington JM. Botulinum toxin: new treatment for temporomandibular disorders. The British journal of oral \& maxillofacial surgery. 2000;38(5):466-471. 